5. Burrows B, Martinez FD, Halonen M, et al. Association of asthma with serum IgE levels and skin-test reactivity to allergens. $N$ Engl J Med. 1989. № 320. P. 271-277.

6. Sunyer J, Antó JM, Castellsagué J, et al. Total serum IgE is associated with asthma independently of specific IgE levels. Eur Respir. J 1996. № 9. P. 1880-1884.

7. Наказ Міністерства охорони здоров'я України від 02.04.02 №_127/18/ Інструкція про порядок проведення специфічної діагностики та імунотерапії алергічних захворювань.

8. B. Leynaert, J. Sunyer, R. Garcia-Esteban et al. Gender differences in prevalence, diagnosis and incidence of allergic and non-allergic asthma: a population-based cohort. Thorax. 2012. № 67. P. 625-631

DOI https://doi.org/10.30525/978-9934-588-81-5-2.49

\title{
ОСОБЛИВОСТІ УРАЖЕННЯ ШКІРИ У ДІТЕЙ НА ТЛІ ХРОНІЧНОГО ЗАКРЕПУ
}

\author{
Конопліцька А. П. \\ кандидат медичних наук, \\ доиент кафедри педіатрії № 1
}

Вінницький національний медичний університет імені М. І. Пирогова

Антонець B. А.

кандидат медичних наук,

доиент кафедри педіатрії № 1

Вінницький національний медичний університет імені М. І. Пирогова

\section{Чорнопищук Н. П.}

асистент кафедри педіатрії № 1

Вінницький національний медичний університет імені М. І. Пирогова

Мазур О. Г.

кандидат медичних наук,

асистент кафедри педіатрії № 1

Вінницький національний медичний університет імені М. I. Пирогова

\section{Плахіна О. С.}

студентка V курсу

Вінницький національний медичний університет імені М. I. Пирогова м. Вінниця, Украӥна

Актуальність. Закрепи є однією з причин звернення до дитячих гастроентерологів, що становить до 25\% звернень до спеціаліста [2]. Подеку- 
ди закрепи уражають й до $30 \%$ дітей і становлять близько $3-5 \%$ всіх візитів до педіатра в США , пік захворюваності припадає на дошкільний вік. Вроджені аномалії розвитку товстої кишки 3 хронічним закрепом у дітей сягає поширеності близько 5\% [1,4]. Останнім часом питання щодо кореляції захворювань шкіри, а саме вугрової хвороби (ВХ) або акне та органів шлунково-кишкового тракту (ШКТ) все більше приваблює спеціалістів з різних галузей медицини, зокрема педіатрів [3]. Виявляється, що взаємозв'язок акне з наявністю закрепів у підлітків призводять до дефіциту нормофлори кишечника та наявності ендогенної інтоксикації, що ускладнює шкірний процес, викликає сенсибілізацію аутофлорою, підтримує запалення слизової оболонки, сприяє збільшенню проникнення стінки кишечника. Порушення динамічної рівноваги біоценозу кишечника призводить до зниження імунологічної реактивності організму, що проявляється хворобливими станами шкіри.

Мета: дослідити особливості перебігу хронічного закрепу та встановити взаємозв'язок з частотою виникнення акне у дітей .

Матеріали та методи. нами було досліджено 61 дитина 3 хронічним закрепом віком 2-17 років, які пройшли стаціонарне обстеження та лікування у педіатричному відділенні №1 ВОДКЛ в період 3 жовтня 2019 по березень 2020 року. Хворих було розподілено на три вікові групи. Першу групу склали пацієнти віком від 2 до 5 років $20(32,7 \%)$ дітей, другу - від 6 до 11 років - 27 (44,2\%) дитини, третю - від 12-17 років - 14 (23,1\%). У дослідженні були використані клінічні, лабораторні та інструментальні методи обстеження.

Результати. У I групі дітей сердній вік хворих був $3,4 \pm 1,1$ років; у II групі $-8,8 \pm 0,8$ років, III група $-13,7 \pm 1,5$ років. Так, серед причин закрепу у дітей I групи переважав хронічний закреп аліментарного генезу - 52\%, та 38\% на тлі ВВВТК: доліхосигми. У дітей II групи 85\% - ВВВТК: доліхосигми, та 10\% ВВВТК: доліхоколон і 5\% - алементарні чинники, III група 56\% ВВВТК: доліхосигма, 38\% III група 3 BВВТК: доліхоколон і 6\% - алементарні чинники. Так, у порівнянні обстежуваних груп дітей з хронічним закрепом ураження шкіри вугровою хворобою було виявлено, що у $65 \%$ вападків III групи було виявлено акне, у II групі - 25\% випадків, I групі таких змін не було виявлено. Діти, у яких було виявлено проблеми шкіри, були консультовані лікарем дерматологом. Після консультації діти продовжили комплексне лікування, скероване на усунення проявів хронічного закрепу та лікування акне.

Висновки:

1. Дослідивши взаємозв'язок між хронічним закрепом та ураженням шкіри у дітей різного віку, ми встановили, що явища ендогенної інтоксикації на тлі хронічного закрепу у дітей III групи у 65\% та 25 \% 
випадків у II групі було виявлено запальні ураження шкіри обличчя. Найбільш притаманним ураження шкіри було для дітей віком після 11 років.

2. Майбутній стан шкіри підлітків залежить від профілактики хронічного закрепу.

\title{
Література:
}

1. Management of functional constipation in children and adults. Vriesman MH, Koppen IJN, Camilleri M, Di Lorenzo C, Benninga MA.Nat Rev Gastroenterol Hepatol. 2020 Jan;17(1):21-39. doi: 10.1038/s41575-019-0222-y. Epub 2019 Nov 5.PMID: 31690829

2. Poddar U. (2016, Apr). Approach to Constipation in Children. Indian Pediatr. 53(4):319-327. https://doi.org/10.1007/s13312-016-0845-9; PMid:27156546

3. Rutten JM, Korterink JJ, Venmans LMAJ, Benninga MA, Tabbers MM. (2017). Guideline on functional abdominal pain in children. Ned Tijdschr Geneeskd. 161:781-789.

4. Tabbers M.M., DiLorenzo C., Berger M.Y., Faure C., Langendam M.W., Nurko S., Staiano A. et al. Evaluation and Treatment of Functional Constipation in Infants and Children: Evidence-Based Recommendations From ESPGHAN and NASPGHAN. J Pediatr Gastroenterol Nutr 2014; 58 (2): 258-275. DOI: 10.1097/MPG.0000000000000266

DOI https://doi.org/10.30525/978-9934-588-81-5-2.50

\section{PREREQUISITES FOR CHOOSING AN EFFECTIVE MODEL OF PROVIDING DERMATOVENEROLOGICAL CARE IN UKRAINE}

\author{
Korolenko V. V. \\ $M D, P h D$,
}

Doctoral Candidate at the Department of Social Medicine and Public Health, Bogomolets National Medical University

Gruzieva T. S.

Doctor of Medical Sciences, Professor, Head of the Department of Social Medicine and Public Health Bogomolets National Medical University

Kyiv, Ukraine

Maintaining the proper level of dermato-venereological health remains extremely important in Ukraine. Skin and subcutaneous tissue diseases 